\title{
Voltage-Dependent L-Type Calcium Channel Subunit Alpha-1D
}

National Cancer Institute

\section{Source}

National Cancer Institute. Voltage-Dependent L-Type Calcium Channel Subunit Alpha-1D. NCI Thesaurus. Code C113771.

Voltage-dependent L-type calcium channel subunit alpha-1D (2161 aa, $245 \mathrm{kDa}$ ) is encoded by the human CACNA1D gene. This protein is involved in calcium transport. 